UDC 621.923 .6

(C) T. Roik, Ph.D., Professor, lu. Vitsiuk, Ph.D., Associate Professor, Igor Sikorsky Kyiv Polytechnic Institute, Kyiv, Ukraine

\title{
THE PROPERTIES OF THE NEW COMPOSITE ANTIFRICTION PARTS FOR PRINTING EQUIPMENT'S FRICTION UNITS
}

The paper summarizes the formation of new materials' structure and properties after using a new hot isostatic-pressing technology. It shows the efficiency of the developed technology of production and the following heat treatment for the new high speed bearings, which is confirmed by the results of complex experimental and industrial tests. Such technology is able to ensure the high and stable level of the functional properties.

The experimental results of the new composite bearing material's properties in a comparison with the already known nickel composite have been presented. The article shows that the dense friction films were formed on the contact surfaces during tribological tests. Friction films protect contact surfaces from intensive wear, and stabilize working of a friction unit in a printing machine. The full-scale industrial tests of EP975- $\mathrm{CaF}_{2}$ bearings showed increase in wear resistance by a factor up to 10 compared with the already known bearings in high speed printing machines' friction units at a load up to $5 \mathrm{MPa}$ and a rotation speed up to $6000 \mathrm{rpm}$.

Keywords: bearing; composite; technology; properties; printing machine.

\section{Introduction}

The questions of using friction materials takes a central place in the general problem with increasing machines' and equipment quality. First of all, it concerns the bearing materials for friction joints, which are falling under the influence of different kinds of contact interaction. Tenure of the use and systematic work of machines are determined by resistance of friction pairs to intensive wear at different exploitation conditions [1-5]. The heaviest operating conditions are high loading (3.0-7.0 MPa), with the temperature $500-600^{\circ} \mathrm{C}$ or high speeds of rotation up to $10000 \mathrm{rpm}$ [2-4].

Such effects are peculiar to the friction units of printing machines (high speed revolution machines), equipment of thermal and rolling shops, and also energy equipment.

The performance of the increased loads, high speeds of the rotation, influence of the oxidizing environment built a list of aggressive fac-

\footnotetext{
(C) $2017 \mathrm{p}$.
} 
tors, which cause the intensive wear rate of the friction units in printing equipment [1-5].

Now, the great variety of cast and composite bearing materials based on ferrous and non-ferrous alloys have been developed and used in hard operating conditions $[4,5]$. An intensive wear and high friction coefficient were connected with an imperfection of the manufacturing technologies. Moreover, a high cost unites these materials. And also, cast materials, which are used in extreme working conditions, such as cast iron, bronze, the non-ferrous alloys are unable to combine different additives in a composition, which would form a strong matrix and contain antiscoring additives, such as sulfides, oxides, chalcogenides, and fluorides [1-4].

The main task in the development of the new composite bearing materials for printing machines is to increase the life of such equipment by, for example, applying lubricants in order to operate under conditions of high loads and rotation speeds on the air.

Among the antifrictional composite materials, intended for severe operating conditions and incorporating solid lubricants, materials based on copper, iron, nickel, cobalt, and ceramics $\left(\mathrm{Al}_{2} \mathrm{O}_{3} /\right.$ $\mathrm{TiC} / \mathrm{CaF}_{2}, \mathrm{Al}_{2} \mathrm{O}_{3} / \mathrm{CaF}_{2} / \mathrm{AgO} / \mathrm{CaF}_{2}$ ) are well known $[1-3,6]$.

The powder composite materials based on iron or alloy powder steel are known for using at speeds $\mathrm{V}<400 \mathrm{rpm}$ and loads up to $3.0 \mathrm{MPa}$. At higher speeds ( $V \geq 600 \mathrm{rpm})$ and loads up to $1.5-5.0 \mathrm{MPa}$, materials based on nickel, cobalt and copper are used [1-4]. This is due to their original physical properties [1].
The already known powder and cast alloys based on nickel (or cobalt) demonstrate unsatisfactory tribotechnical properties - high friction coefficient, and wearing at heavy-duty conditions of printing machines $[1,5]$.

Therefore, as a basis for bearings materials, a composite nickel alloy was selected - marked as EP975 for heavy-duty conditions, such as increased loadings, air environment, and rotation speeds 4000-6000 rpm. This choice was caused by the complete absence of known alloys' operability of both cast and powder on the basis of copper, iron, nickel under such operation conditions. The big number of alloy elements in the nickel matrix (more than 35 mas. \%) gives the alloy EP975 high physical and physical-mechanical properties [7, 8].

At the high rotation speeds of printing machines, any liquid lubricant is disabled because the liquid lubricant was thrown out from the friction zone by the centrifugal forces. It is especially important to protect the friction surfaces from the increased wearing and frictional seizure. Numerous studies show that using solid lubricants as an embedded component of materials improves the tribotechnical characteristics of the plain bearings [1-5]. For instance, calcium fluoride $\mathrm{CaF}_{2}$ as a thermal and chemical stable substance is widely used as a solid lubricant to improve frictional contact, especially in heavy-duty conditions [7-9].

These arguments were a reason for complex researches, which were directed for studying tribotechnical properties of the new bearings for loadings of 3.0-5.0 MPa 
and rotation speeds by $4000-6000$ rpm on the basis of the scientifically grounded material science approach with the purpose to obtain the possibility of prognostics and control of materials functional properties.

Moreover, it is of the theoretical and practical importance to establish the structure and properties, distribution of $\mathrm{CaF}_{2}$ over the metal matrix, and its effect on the friction behavior of nickel alloy EP975-based materials under extreme operating conditions of printing machines.

The objective of the present paper is to research the bearing nickel alloy EP975-based composite materials with a $\mathrm{CaF}_{2}$ additions for heavy-duty conditions (high rotation speeds and loads), to study the formation physical mechanical and tribotechnical properties of the new bearings.

\section{Experimental results and discussion}

The structure was studied using a raster electron microscope; calcium fluoride in the matrix was identified by using a scanning electron microscopy (SEM). The physic mechanical properties of the samples were determined as well. Tribological tests were performed on a VMT-1 friction testing machine (rotation speeds $\mathrm{V}=4000-6000 \mathrm{rpm}$, and pressure $\mathrm{P}=5.0 \mathrm{MPa}$ ), the counterface is made of R18 tool steel $(H R C=53-55)$; shaft-pin friction pair.

The powders of the highalloyed nickel alloy EP975 have been produced by the powder spraying method of metal melted by argon stream. Dispersed metal drops were crystallized as spheri- cal particles with the dimensions from 10 to $750 \mu \mathrm{m}$. Usually, optimum dimensions of the fractions are in the range of $37-250 \mu \mathrm{m}$. In our case, powders of alloy EP975 were of $50-250 \mu \mathrm{m}$. Chemical composition of materials was the following with the mass. \%: $\mathrm{C}-0.038$ 0.076; W-8.65-9.31; $\mathrm{Cr}-7.6-9.5$; Mo - 2.28-3.04; $\mathrm{Ti}-1.71-2.09$; $\mathrm{Al}$ - 4.75-5.13; Nb - 1.71-2.59; Co - 9.5-11.4; $\mathrm{Ni}$ - basis, $\mathrm{CaF}_{2}-$ 4.0-8.0 [7].

Thus, in our experiments, we researched the bearing compositions - EP975+(4.0-8.0)\% $\mathrm{CaF}_{2}$.

The hard spherical powder particles of the high-alloyed nickel alloy EP975 are a real microingot that excludes the problem of liquation at once. This problem is typical for the cast nickel alloys obtained by traditional technology [1-5].

The method of a hot isostaticpressing (HIP) was used in manufacturing of new bearing materials, because the traditional technology of powder metallurgy doesn't ensure minimum porosity.

The hot isostatic pressing (or gas-static pressing) was executed on the special presses - gasostat. The hot isostatic pressing was carried out in a liquid (hydrostatical) or gas (gasostatical) environment. A working environment was forced to a hermetic chamber by compressors, and creates a pressure of few thousand bars. The isostatic pressing can combine high pressure with high temperature, which allows combining the process of forming and sintering $[1-4,7]$.

First of all, the initial components of the sprayed powders of nickel alloy EП975 and solid lubri- 
cant $\left(\mathrm{CaF}_{2}\right)$ were mixed up during 4-6 hours. And then the mixed powders were loaded to the special steel containers. The filled containers were pressurized to set a vacuum density. The process of hot isostatic pressing was carried out at $1210 \pm 10^{\circ} \mathrm{C}$, during 4 hours, under pressure of argon up to $140 \mathrm{MPa}$.

The hot isostatic pressing allows obtaining enough dense materials, almost without pores. The blanks had a relative density of $99.9 \%$.

After the hot isostatic pressing, a heat treatment was carried out for optimization of dispersible phases' morphology in the structure of materials and for obtaining a necessary level of physical mechanical and antifriction properties.

The heat treatment includes hardening - heat to $1240^{\circ} \mathrm{C}$ during 4 hours, cooling with the speed at 40 degrees/hour in a furnace of $1200^{\circ} \mathrm{C}$, then cooling on the air.
After a hardening an ageing was carried out at $910^{\circ} \mathrm{C}$ during 16 hours on the air.

The HIP with a next heat treatment have been ensured the formation of phases in a structure that increase the physical-mechanical properties of materials (combination of the strength and plasticity), and improve operating reliability of a friction part.

A microstructure of the new composite bearing material EP975+8 \% $\mathrm{CaF}_{2}$ after heat treatment is presented in figure 1.

The structure of the material is heterogeneous. There is a metallic matrix with inclusions of solid lubricant $\mathrm{CaF}_{2}$. The solid lubricant $\mathrm{CaF}_{2}$ particles were uniformly arranged [8, 9]. The presence of a big number of alloy elements in a nickel matrix gives the new bearing materials a high level of physical-mechanical and tribotechnical properties. The tribotechnical and physical-mechanical properties of new materials have been presented in the tables 1,2 in a

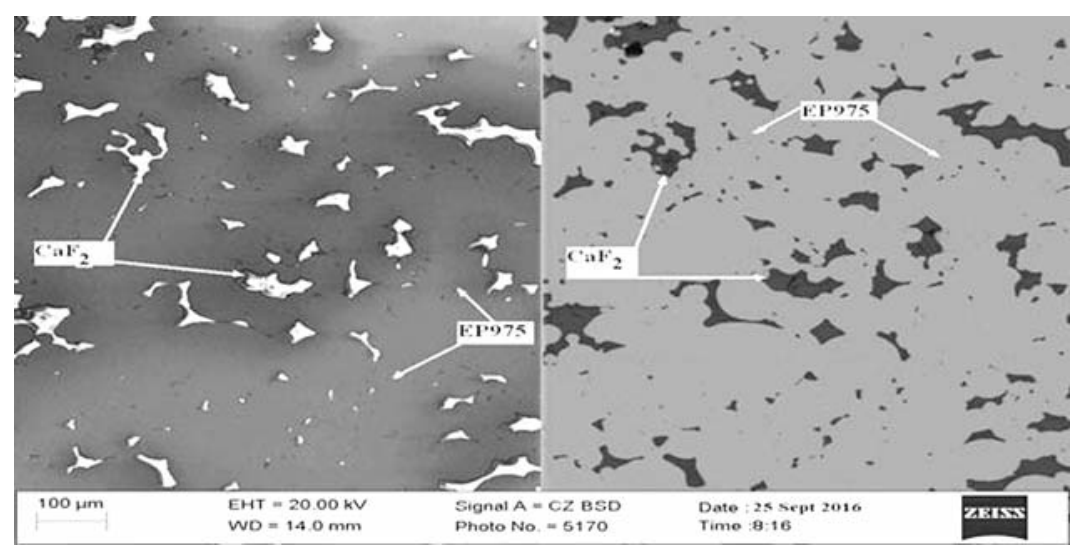

a

b

Fig. 1. The microstructure of EP975 $+6 \% \mathrm{CaF}_{2}$ material (raster electron microscope): $a-$ image in secondary electrons; $b$ - phase contrast image 
comparison with the known Ni-powder material [1], which is applied under the analogue conditions.

Analysis of the information in the tables 1, 2 evidently showed that the new high-speed bearings materials on the basis of EP975 alloy with the addition of $\mathrm{CaF}_{2}$ have higher properties in comparison with the known material [1], and they are able to operate at the higher rotation speeds and loads.

During the tribological tests, the dense friction films were formed on the contact surfaces, both on the surface of examined materials and counterface (figure 2 ).
As shown in figure 2, all the friction surfaces are covered by the dense antiscoring films, the so-called as secondary structures. They consist of the chemical elements of bearing and counterface, and solid lubricant $\mathrm{CaF}_{2}$. During the friction process, the different chemical reactions took place between $\mathrm{O}_{2}$ of the air and elements of researched specimen and steel R18 counterface at high rotation speeds and loads. Such chemical processes result in formation of friction films, which protect contact pairs against intensive wear and stabilize a work of friction unit in printing machine.

Table 1

Strength properties of materials at room temperature

\begin{tabular}{|c|c|c|c|c|c|}
\hline$\#$ & Composition, mas. \% & $\begin{array}{c}\text { Ultimate } \\
\text { stress } \\
\text { at tension, } \\
\sigma_{\mathrm{t}}, \mathrm{MPa}\end{array}$ & $\begin{array}{c}\text { Yield } \\
\text { strength, } \\
\sigma_{0,2}, \mathrm{MPa}\end{array}$ & $\begin{array}{c}\text { Extension } \\
\text { strain, } \delta, \%\end{array}$ & $\begin{array}{c}\text { Contraction, } \\
\psi, \%\end{array}$ \\
\hline 1 & 1200 & 800 & 14 & 14 \\
\hline 2 & $\begin{array}{c}\text { EP975 (powder, made } \\
\text { by gas-static pressing } \\
\text { technology) }\end{array}$ & 1400 & 1120 & 12 & 15 \\
\hline 3 & $\begin{array}{c}\text { EP975 + 6CaF } 2 \text { (powder, } \\
\text { made by gas-static } \\
\text { pressing technology) }\end{array}$ & 1100 & 900 & 10 & 12 \\
\hline
\end{tabular}

Table 2

Antifriction properties of materials based on alloy EP975

\begin{tabular}{|c|c|c|c|c|c|}
\hline \# & Composition, mas. \% & $\begin{array}{l}\text { Friction } \\
\text { coefficient }\end{array}$ & $\begin{array}{l}\text { Wear, } \mu / \mathrm{km} \\
(V=1200 \\
\text { rpm })\end{array}$ & $\begin{array}{l}\text { Limit load, } \\
\text { MPa }\end{array}$ & $\begin{array}{l}\text { Limit rotation } \\
\text { speed, rpm }\end{array}$ \\
\hline 1 & $\mathrm{EP} 975+4 \% \mathrm{CaF}_{2}$ & 0,27 & 57 & 5 & 6000 \\
\hline 2 & $\mathrm{EP} 975+6 \% \mathrm{CaF}_{2}$ & 0,26 & 54 & 5 & 6000 \\
\hline 3 & $\mathrm{EP} 975+8 \% \mathrm{CaF}_{2}$ & 0,27 & 58 & 5 & 6000 \\
\hline 4 & $\begin{array}{l}\mathrm{Ni}+(18-5 \%) \mathrm{MoB}_{2}+ \\
\left.+\mathrm{ZrB}_{2}\right)+5 \%\left(\mathrm{CaF}_{2} \text { or }\right. \\
\left.\mathrm{BaF}_{2}\right) \text { sintered alloy }[1]\end{array}$ & 0,31 & 780 & 1,5 & 1500-2000 \\
\hline
\end{tabular}




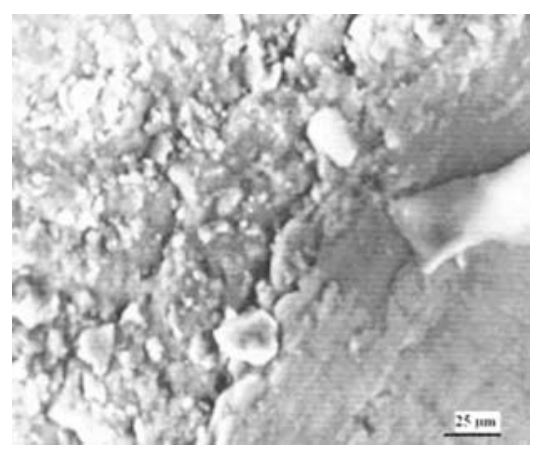

a

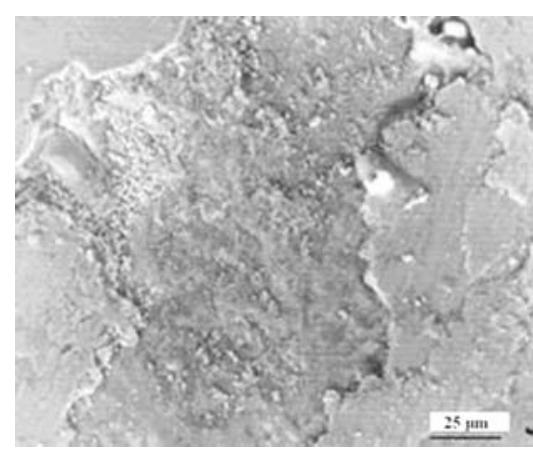

b

Fig. 2. Images of the friction surfaces: a $-\mathrm{EP} 975+6 \% \mathrm{CaF}_{2}$ material; b - counterface of steel R18

\section{Conclusions}

We have developed a new effective bearing materials, based on $\mathrm{Ni}$ alloy EP975- $\mathrm{CaF}_{2}$ system with high physical mechanical and tribotechnical properties performing well in more severe conditions than the already known sintered alloy.

The new materials have an advantageous level of tribotechnical characteristics due to the tri- bofilms formed on the contact surfaces by dragging of calcium fluoride to cover the entire friction area.

The full-scale industrial tests of EP975- $\mathrm{CaF}_{2}$ bearings showed increase in wearing resistance by a factor up to 10 compared with the already known bearings in friction units of the Heidelberg Speedmaster SM-102-FPL and KBA Rapida-105 high speed printing machines.

\section{References}

1. Roik, T. A. \& Kyrychok, P. O. \& Havrysh, A. P. (2007). Composite bearing materials for higher operation conditions. Kyiv: NTUU 'KPI' [in Ukrainian].

2. Havrysh, A. P. \& Kyrychok, P. A. \& Roik, T. A. \& Zorenko, O. V. \& Oliinyk, V. H. (2016). Precision grinding and polishing of printing machines' parts from highalloyed composites. Kyiv: NTUU 'KPI' [in Ukrainian].

3. Roik, T. A. \& Havrysh, A. P. \& Gavrysh, O. A. (2010). Modern technologies' systems of billet production in machine building. Kyiv: ECMO [in Ukrainian].

4. Gavrish, A. P. \& Melnik, O. A. \& Roik, T. A. \& Askerov, M. G. \& Gavrish, O. A. (2012). New finishing technologies of composite sliding bearings for heavyduty exploitation conditions. Kyiv: NTUU 'KPI' [in Russian].

5. Kyrychok, P. O. \& Roik, T. A. \& Havrysh, A. P. \& Shevchuk, A. V. \& Vitsiuk, lu. lu. (2015). New Composite Materials of the friction parts for printing machines. Kyiv: NTUU 'KPI' [in Ukrainian].

6. Jianxin, D. \& Tongkun, C. (2007). Self-lubricant mechanisms via the in situ formed tribofilm of sintered ceramics with $\mathrm{CaF}_{2}$ additions when sliding against hardened steel. Journal of J. Refract. Met. Hard Mater., 25, No. 2, 189-197 [in English]. 
7. Roik, T. A. \& Havrysh, A. P. \& Kyrychok, P. O. Composite Bearing Material // Ukrainian Patent No. 60521, IPC (2009), C22C9/02, Bulletin No. 12, Publ. June 25, 2011 [in Ukrainian].

8. Roik, T. A. \& Kholyavko, V. V. \& Vitsiuk, lu. lu. (2009). Influence of mechanism tribosynthesis of secondary structures for properties of antifriction composites materials based on nickel. Journal of Met. Fiz. Nov. Tekhn., 31, 1001-1016 [in Ukrainian].

9. Roik, T. A. \& Havrysh, A. P. \& Kyrychok, P. O. \& Vitsiuk, lu. lu. (2015). Effect of secondary structures on the functional properties of high-speed sintered bearings for printing machines. Journal of Powder Metallurgy and Metal Ceramics: Springer, New York, Volume 54, Issue 1, 119-127 [in English].

У статті висвітлено формування структури і властивостей нових матеріалів після використання нової технології гарячого ізостатичного пресування. Показано ефективність розробленої технології виготовлення та наступної термічної обробки для нових високошвидкісних підшипників, що підтверджено результатами комплексних експериментальних і промислових випробувань. Така технологія здатна забезпечити високий і стабільний рівень функціональних

властивостей. Представлено результати експериментальних досліджень властивостей нового підшипникового композиційного матеріалу порівняно з вже відомим нікелевим композиційним сплавом. Показано, що під час трибологічних випробувань сформовано щільні плівки тертя на контактних поверхнях. Фрикційні плівки захищають контактні поверхні від інтенсивного зносу та стабілізують роботу вузла тертя в друкарській машині. Повномасштабні промислові випробування підшипників з нового матеріалу ЕП975- $\mathrm{CaF}_{2}$ показали збільшення зносостійкості до 10 разів порівняно з вже відомими деталями,

що працюють у вузлах тертя друкарських машин при навантаженні до 5 МПа та швидкостях обертання до 6000 об./Хв.

Ключові слова: підшипник; композиційний матеріал; технологія; властивості; друкарська машина.

В статье представлено формирование структуры и свойств новых материалов, полученных с помощью новой технологии горячего изостатического прессования. Показана эффективность разработанной технологии изготовления и последующей термической обработки новых высокоскоростных подшипников, что подтверждено результатами комплексных экспериментальных и промышленных испытаний. Данная технология способна обеспечить высокий и стабильный уровень функциональных свойств. Представлены результаты экспериментальных исследо- 
ваний свойств нового подшипникового композиционного материала по сравнению с уже известным никелевым композиционным сплавом. Показано, что во время трибологических испытаний сформированы плотные пленки трения на контактных поверхностях. Фрикционные пленки защищают поверхности контакта от интенсивного износа и стабилизируют работу узла трения печатной машины. Полномасштабные промышленные испытания подшипников из нового материала EП975- $\mathrm{CaF}_{2}$ показали увеличение износостойкости до 10 раз по сравнению с известными, которые работают в узлах трения печатных машин при нагрузке до 5 МПа и скоростях вращения до 6000 об./мин.

Ключевые слова: подшипник; композиционный материал; технология; свойства; печатная машина.

Рецензент - О. І. Лотоцька, к.т.н., доцент, КПІ ім. Ігоря Сікорського 